\title{
Temporal association between hospital admissions for asthma in Birmingham and ambient levels of sulphur dioxide and smoke
}

\author{
Sarah Walters, R K Griffiths, J G Ayres
}

\begin{abstract}
Background - A study was performed to determine whether daily and weekly variations in the levels of smoke and sulphur dioxide $\left(\mathrm{SO}_{2}\right)$ in Birmingham are related to hospital admissions for asthma and acute respiratory diseases.
\end{abstract}

Methods - Daily numbers of hospital admissions for asthma (ICD code 493) and acute respiratory conditions (ICD 466, 480-486, 490-496) for residents of Birmingham between 1988 and 1990 were obtained from West Midlands RHA Körner inpatient data. Average daily levels of sulphur dioxide and smoke were obtained from Birmingham City Council for the same period, together with daily meteorological summaries from the Department of Geography, University of Birmingham. With the exception of one day, all air pollution measurements remained within current EC guide levels. Data were divided into seasons and the relation between hospital admissions and pollutant levels were explored by stepwise least squares regression models. Meteorological variables (temperature, pressure, humidity) were entered into the model if they showed significant association with hospital admissions during the season in question. Analysis was undertaken for daily (same day and lagged by two days) and weekly pollutant levels. Admissions were lagged behind pollution levels to allow for delayed effects of pollutants.

Results - The mean daily level of smoke was $12 \cdot 7 \mu \mathrm{g} / \mathrm{m}^{3}$ and of $\mathrm{SO}_{2}$ was $39 \cdot 1 \mu \mathrm{g} / \mathrm{m}^{3}$, with maxima of $188.3 \mu \mathrm{g} / \mathrm{m}^{3}$ and $126.3 \mu \mathrm{g}$ / $\mathbf{m}^{3}$, respectively. Significant associations were found between hospital admissions for respiratory disease lagged by two days, and smoke and $\mathrm{SO}_{2}$ levels during winter. Associations between admissions for asthma and smoke and $\mathrm{SO}_{2}$ levels were significant at the $5 \%$ level. These were independent of temperature, pressure, and humidity. Stepwise regression including both pollutants showed that smoke, but not $\mathrm{SO}_{2}$, was a significant independent predictor of hospital admissions for both asthma and all respiratory conditions. During winter a rise of $100 \mu \mathrm{g} /$ $\mathrm{m}^{3}$ smoke might result in five (95\% CI 0.6 to 9) more asthma admissions and 21.5 (95\% CI 10 to 33 ) more acute respiratory admissions each day in Birmingham. A $100 \mu \mathrm{g} / \mathrm{m}^{3}$ rise in $\mathrm{SO}_{2}$ might result in four
(0 to 7$)$ more asthma admissions and $15 \cdot 5$ (6 to 25 ) more respiratory admissions each day. Independent associations were also found between weekly mean smoke and $\mathrm{SO}_{2}$ levels and all respiratory admissions during autumn and winter. During summer, daily mean smoke and $\mathrm{SO}_{2}$ levels were significantly associated with non-lagged daily admissions for all respiratory diseases $(p<0.02)$. There was no association between air pollution and hospital admissions during spring.

Conclusions - Daily variations in smoke and $\mathrm{SO}_{2}$ levels are significantly associated with hospital admissions for asthma and respiratory disease during winter in Birmingham at levels of air pollutants within the EC guide levels. This association was independent of potential confounding effects of weather (temperature, pressure, humidity) and suggests that current levels of air pollution can still produce significant health effects.

(Thorax 1994;49:133-140)

The effects of air pollution on public health have been studied for many years. Studies of both short term health effects of temporal changes in air pollution levels, and long term effects on prevalence of disease and mortality, have been undertaken. Study methods used have included epidemiological studies - both ecological and planned observations - and controlled exposure experiments. Epidemiological studies have addressed a wide range of potential health outcomes including mortality, hospital attendances and admissions, and changes in symptoms and respiratory function. Despite all this work the exact nature and scale of the public health effects of air pollution, and the levels of pollutants at which health effects occur, remain unclear.

In 1952 a severe smog in London with exceptionally high levels of sulphur dioxide $\left(\mathrm{SO}_{2}\right) \quad\left(4000 \mu \mathrm{g} / \mathrm{m}^{3}\right)$ and smoke (estimated $7000-8000 \mu \mathrm{g} / \mathrm{m}^{3}$ ) resulted in more than 4000 deaths from respiratory and cardiovascular disease. ${ }^{1}$ Following this episode, clean air legislation successfully reduced $\mathrm{SO}_{2}$ and smoke levels throughout the UK. ${ }^{2}$ With falling levels of these pollutants, interest and research into their effects on health waned in the UK. Studies from the USA suggest that current lower levels of particulates are still associated with mortality. A consistent independent relation has been shown between both total suspended particulates ${ }^{34}$ and particulates below 
$10 \mu \mathrm{m}$ in diameter (PM10) $)^{56}$ and daily mortality; the relation is strongest in patients with respiratory and cardiovascular conditions.

The effect of $\mathrm{SO}_{2}$ and particulates on hospital admissions or attendances has also been studied. A series of Canadian studies showed significant relations between hospital admissions for asthma and respiratory diseases and air pollution. Admissions were significantly associated with levels of $\mathrm{SO}_{2}$, coefficient of haze, and a composite air pollution index in southern Ontario. ${ }^{7}$ Bates and Sizto showed a relation between hospital admissions for asthma and respiratory diseases and levels of $\mathrm{SO}_{2}$, ozone, oxides of nitrogen and sulphate during summer. ${ }^{8}$ In Vancouver, $\mathrm{SO}_{2}$ was significantly associated with attendances at the emergency department for asthma and respiratory diseases during both summer and winter. ${ }^{9}$ This study also showed a significant association during summer between hospital attendances and sulphate and ozone levels. A recent study from Barcelona showed significant, though weak, relations between $\mathrm{SO}_{2}$, smoke and carbon monoxide levels and hospital attendances in patients with chronic obstructive pulmonary disease (COPD) ${ }^{10}$

An important series of recent studies from Utah on the effects of PM10 pollution on various health outcomes has confirmed health effects of relatively low levels of particulates. Hospital admissions rose by $89 \%$ in children and by $47 \%$ in adults when PM10 levels exceeded $50 \mu \mathrm{g} / \mathrm{m}^{3} .{ }^{11}$ In a later study hospitalisation rates for Utah Valley were compared with those in two other valleys during a period of steel mill closure. Hospital admission rates were high in the polluted Utah Valley, but fell almost to those in the comparison valleys during closure of the mill, and rose again rapidly after reopening. ${ }^{12}$ A study from Seattle confirmed the association between hospital attendances for asthma and PM10 levels. ${ }^{13}$ Further studies from Utah have shown PM10 to be associated with school absences, even when corrected for weather. ${ }^{14}$ Peak expiratory flow (PEF) in panels of children is significantly associated with PM10, even when days above the air quality standard of $150 \mu \mathrm{g} / \mathrm{m}^{3}$ were excluded. ${ }^{15}$ The association was stronger for children with respiratory symptoms.

Early panel studies showed a relation between daily smoke and $\mathrm{SO}_{2}$ levels in London and symptoms in patients with COPD ${ }^{16}$; however, pollution levels were considerably higher than at present. More recent studies in normal children in Holland showed an average 5\% decrement in forced expiratory volume in one second $\left(\mathrm{FEV}_{1}\right)$ during two pollution episodes $\left(\mathrm{SO}_{2}\right.$ and total suspended particulate levels $\left.200-300 \mu \mathrm{g} / \mathrm{m}^{3}\right) .{ }^{1718} \mathrm{~A}$ large panel study in Holland in normal and asthmatic children showed an association between PEF, wheeze, bronchodilator use, and levels of PM10, smoke, and $\mathrm{SO}_{2}{ }^{19}$ A US study reported similar findings. ${ }^{20}$ Levels of total suspended particulates and nitrogen dioxide $\left(\mathrm{NO}_{2}\right)$ were associated with daily reported cases of croup in Germany - a $27 \%$ rise in cases for a $60 \mu \mathrm{g} / \mathrm{m}^{3}$ rise in particulates. ${ }^{21}$
Other pollutants, alone or in combination with $\mathrm{SO}_{2}$ and particulates, have also been associated with health effects. In a panel study in Denver hydrogen ion concentration was significantly associated with several symptomatic indices of asthmatic status, as were fine particulates and sulphate. ${ }^{22}$ In Los Angeles, risk of asthma attacks was increased on days with high oxidant and particulate pollution. ${ }^{23}$ Several studies in summer camps have confirmed that ozone levels can affect pulmonary function. ${ }^{24} 25$

There is good experimental evidence to back up these epidemiological findings. $\mathrm{SO}_{2}$ can cause bronchoconstriction at high levels in normal subjects, ${ }^{26}$ but asthmatic subjects appear to react at one tenth of the concentration. ${ }^{27}$ The effect is increased by exercise ${ }^{2829}$ and may occur after exposure of five minutes or less. ${ }^{30}$ Ozone $e^{3132}$ and $\mathrm{NO}_{2}{ }^{33}$ have also been shown to cause bronchoconstriction, either directly or via their effects on bronchial sensitivity. ${ }^{34}$

As well as studies of acute effects, there is some evidence that exposure to air pollution can produce longer term effects on symptom prevalence. The Harvard Six Cities study reported an association between prevalence of cough, bronchitis, and chest illness in children and ambient particulate and $\mathrm{SO}_{2}$ levels. ${ }^{35}$ This was subsequently confirmed in a second study which showed symptom prevalence to be more strongly associated with particulate levels than $\mathrm{SO}_{2}$ or $\mathrm{NO}_{2}{ }^{36}$ Associations were stronger in children with asthma, and for fine particulates (PM15).

Thus there is a substantial amount of published literature to show that particulate pollution and $\mathrm{SO}_{2}$ is associated with acute health effects. However, there are no recent studies from the UK of health effects at current levels of particulate and $\mathrm{SO}_{2}$ pollution. Hospital admissions for asthma are rising in the West Midlands, particularly in children. ${ }^{37}$ This study sought to determine whether $\mathrm{SO}_{2}$ and smoke (the only available measure of particulates) were associated with hospital admissions for asthma and respiratory disease in Birmingham, to determine the size and potential public health importance of any association seen, and to establish whether these health effects could be detected using routinely collected data.

\section{Methods}

DATA SOURCES

Data on hospital admissions for residents of Birmingham admitted to hospital within the West Midlands Region were obtained in the form of a Körner minimum inpatient data set from the information department at West Midlands Regional Health Authority. This included all patients admitted with a diagnosis of asthma or acute respiratory disease (ICD-9 codes 466, 480-486 and 490-496) for the period April 1988 to March 1990.

Air pollution data were obtained from the Environmental Protection Unit at Birmingham City Council for the same time period. 
Particulate pollution was measured by the British standard black smoke method. ${ }^{38}$ This method has the disadvantage that it measures only coloured particulates, which may constitute a variable proportion of total particulates, and in urban areas this may be a minority. ${ }^{39} \mathrm{~A}$ high proportion of the smoke in urban areas comes from diesel exhaust emissions. ${ }^{40}$ Use of the black smoke method in cities is likely to underestimate total particulate load, and particularly acid aerosols which may also cause health effects. Unfortunately, black smoke was the only measurement method used at the time of the study. It is recognised that use of black smoke will have underestimated total particulate exposure. Sulphur dioxide was measured by the hydrogen peroxide absorption method..$^{38}$ Both pollutants were measured at seven sites in Birmingham, and data were provided as 24 hour mean levels $\left(\mu \mathrm{g} / \mathrm{m}^{3}\right)$. Full meteorological summaries including information about temperature, barometric pressure, and relative humidity were provided by the University of Birmingham Department of Geography for the period April 1988 to March 1990.

\section{ANALYSIS}

Data on daily total hospital admissions, air pollution levels, and meteorological conditions were stored and analysed on a personal computer using the Epi-Info and SPSS for Windows statistical packages, and Quattro Pro for Windows.

The data were divided into seasons as follows: spring (March, April, May), summer (June, July, August), autumn (September, October, November) and winter (December, January, February), since both hospital admissions and air pollution mixtures differ markedly by season. During summer, smoke and $\mathrm{SO}_{2}$ are mixed with ozone, acid aerosols, and other secondary photochemical pollutants for which contemporary data were not available. There are also other potential environmental cofactors such as airborne pollen and spores which show seasonal patterns. Asthma admis-

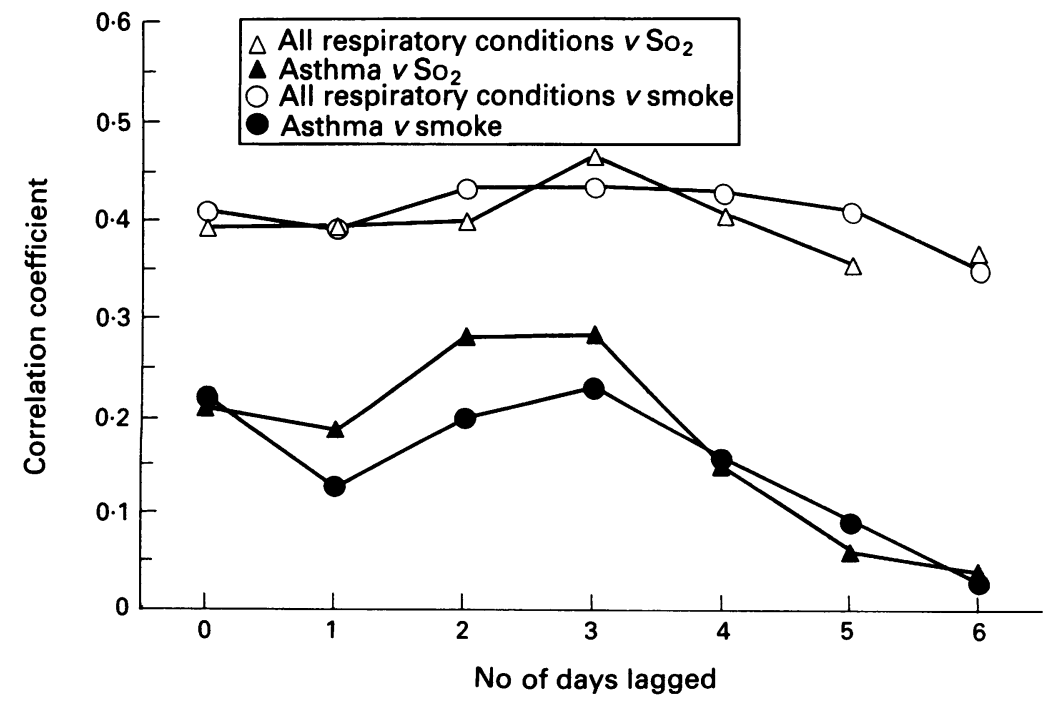

Figure 1 Correlation coefficient for relation between lagged hospital admissions, Birmingham, winter 1988-90. sions show seasonal peaks in early summer and autumn. Because each season shows different atmospheric chemistry characteristics and different potential covariates such as pollen and respiratory infection, the relations between pollution and hospital admissions were examined seasonally. This approach has been taken by other authors. ${ }^{89}$

Analysis was performed by least squares regression. For each season the bivariate relation between hospital admissions and three meteorological variables was determined by simple least squares regression. Those meteorological variables showing a significant $(\mathrm{p}<0.05)$ association with hospital admissions in each season were entered into a least squares regression model along with each pollutant in turn. Stepwise multiple regression models were also constructed using each pollutant in turn and both pollutants together. Regression coefficients ( $\beta$ coefficients), $95 \%$ confidence intervals, and $\mathrm{p}$ values were calculated for the relation between each pollutant and hospital admissions for asthma and all respiratory conditions. This was repeated with hospital admissions lagged two days behind pollution variables to allow for delayed effects, as previously described. ${ }^{9}$ During the winter only, analysis was repeated using successive daily lags for hospital admissions, and the strongest associations obtained when admissions were lagged two to four days behind pollution peaks (fig 1). Because of this, regression models were also developed using three day moving average levels of pollutant. For all models the degree of autocorrelation in the dependent variable was estimated by the Durbin-Watson statistic.

Similar regression models were developed for the association between weekly mean pollutant levels and weekly total hospital admissions for asthma and all respiratory diseases, without lagging of hospital admissions, to examine the effect of more prolonged exposure to high levels of pollutant over a period of several days.

In total, 60 multiple regression models were constructed, and seven additional bivariate regressions were carried out to assess the degree to which hospital admission lagged behind pollutant levels. For this reason the level of statistical significance used in this study was $1 \%$.

\section{Results}

TEMPORAL PATTERNS IN AIR POLLUTION AND HOSPITAL ADMISSIONS

Temporal variations in weekly mean smoke and $\mathrm{SO}_{2}$ levels are shown in fig 2 , and variations in weekly total hospital admissions for asthma and all respiratory conditions are shown in fig 3. Levels of smoke showed consistent winter peaks, but $\mathrm{SO}_{2}$ peaked at other times of year as well. All respiratory admissions showed consistent winter peaks with smaller peaks during spring. Asthma admissions showed peaks during early summer and autumn, but also at other times of year. The mean levels and 10 th to 90 th centiles of smoke and $\mathrm{SO}_{2}$ are given in table 1 , and similar 
figures for asthma and respiratory admissions are presented in table 2 . The mean daily smoke level was $12 \cdot 7 \mu \mathrm{g} / \mathrm{m}^{3}$ over the two year period, and the mean level of $\mathrm{SO}_{2}$ was $39 \cdot 1 \mu \mathrm{g} / \mathrm{m}^{3}$. The maxima were $188.3 \mu \mathrm{g} / \mathrm{m}^{3}$ and $126.3 \mu \mathrm{g} / \mathrm{m}^{3}$ respectively.

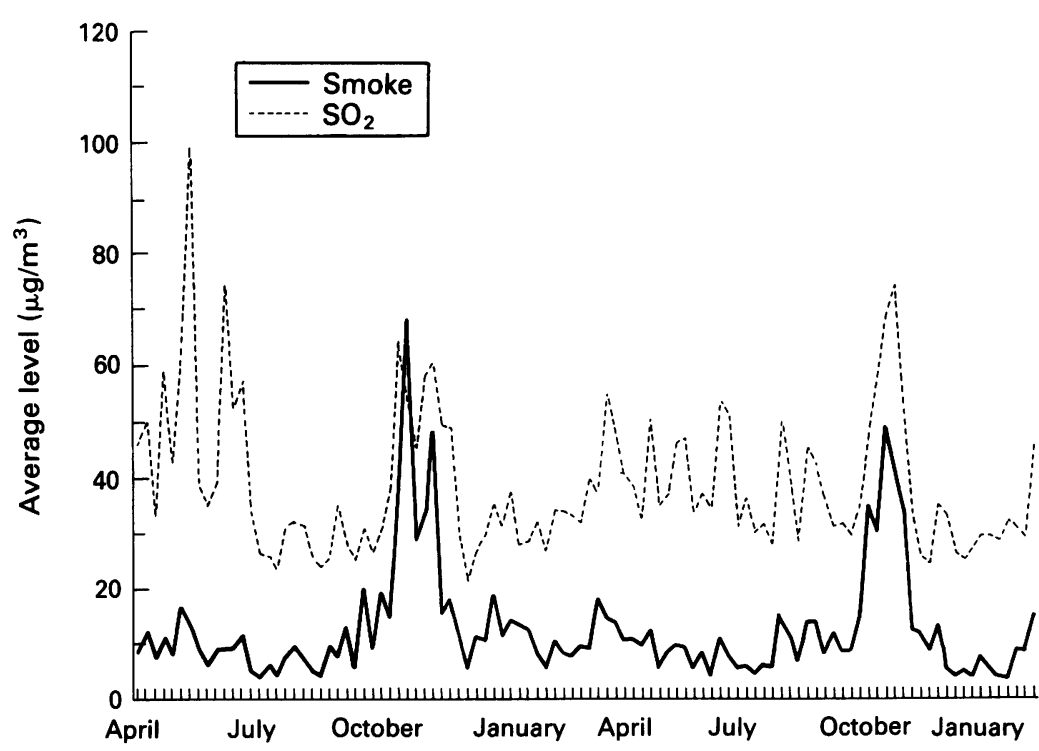

Figure 2 Mean weekly levels of smoke and sulphur dioxide, Birmingham, April 1988 to March 1990.

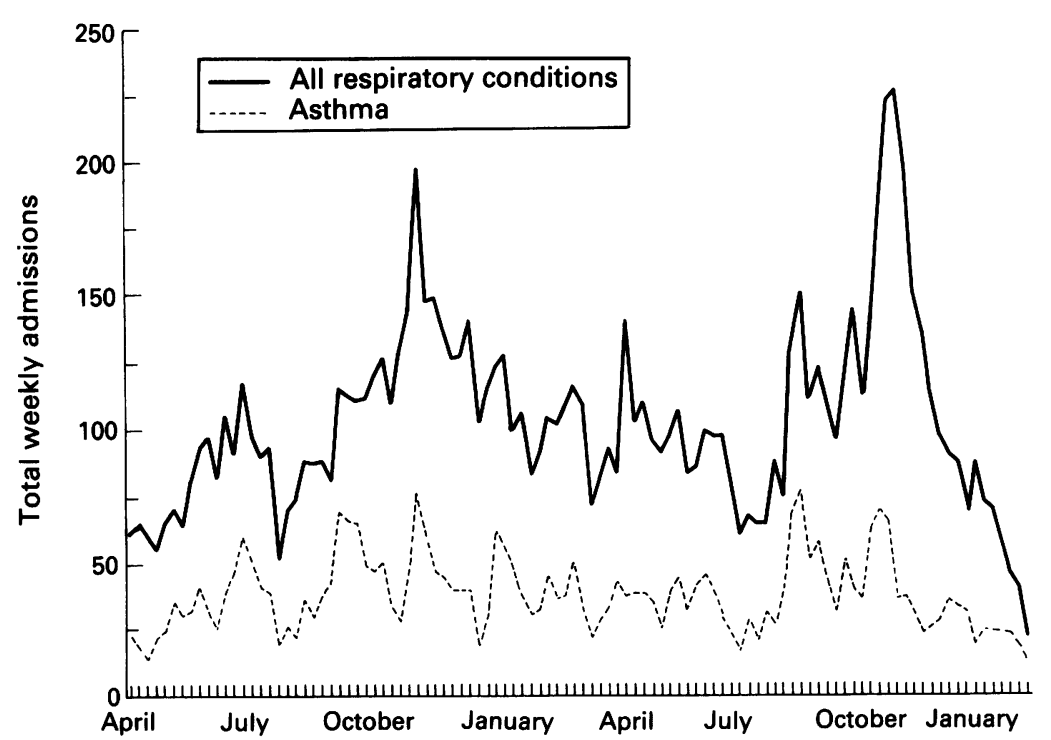

Figure 3 Weekly total admissions for asthma and respiratory disease, Birmingham residents, April 1988 to March 1990.

Table 1 Mean (SE) and centile points for levels of smoke and sulphur dioxide $\left(\mu \mathrm{g} / \mathrm{m}^{3}\right)$ in Birmingham, 1988-90

\begin{tabular}{|c|c|c|c|c|c|c|}
\hline & \multirow[t]{2}{*}{ Mean (SE) } & \multicolumn{5}{|c|}{ Centiles } \\
\hline & & 10th & $25 t h$ & 50 th & $75 t h$ & 90 th \\
\hline $\begin{array}{l}\text { Smoke } \\
\text { Spring } \\
\text { Summer } \\
\text { Autumn } \\
\text { Winter } \\
\text { All year }\end{array}$ & $\begin{array}{r}10.15(0.48) \\
7.19(0.29) \\
20.53(1.74) \\
12.56(0.91) \\
12.74(0.54)\end{array}$ & $\begin{array}{l}4 \\
3 \\
4 \\
4 \\
4\end{array}$ & $\begin{array}{l}5 \\
4 \\
7 \\
5 \\
5\end{array}$ & $\begin{array}{r}9 \\
6 \\
13 \\
8 \\
8\end{array}$ & $\begin{array}{l}14 \\
10 \\
24 \\
15 \\
15\end{array}$ & $\begin{array}{l}19 \\
12 \cdot 5 \\
45 \\
29 \\
25\end{array}$ \\
\hline $\begin{array}{l}\text { Sulphur dioxide } \\
\text { Spring } \\
\text { Summer } \\
\text { Autumn } \\
\text { Winter } \\
\text { All year }\end{array}$ & $\begin{array}{l}42.87(1.35) \\
37.77(1.17) \\
40.91(1.24) \\
34.18(1.03) \\
39.06(0.62)\end{array}$ & $\begin{array}{l}27 \\
23 \\
26 \\
22 \\
24\end{array}$ & $\begin{array}{l}31 \\
27 \\
29 \\
25 \cdot 2 \\
28\end{array}$ & $\begin{array}{l}37 \\
34 \\
36 \\
30 \\
34\end{array}$ & $\begin{array}{l}49 \\
45 \\
48 \\
37 \cdot 7 \\
46\end{array}$ & $\begin{array}{l}64 \cdot 5 \\
55 \cdot 5 \\
68 \\
52 \\
62\end{array}$ \\
\hline
\end{tabular}

RELATION BETWEEN HOSPITAL ADMISSIONS AND AIR POLLUTION

Daily pollution levels and hospital admission

Results of multiple least squares regression models for daily levels of air pollution and daily hospital admissions are shown by season, and for zero and two day lags in hospital admissions in table 3. During winter daily levels of smoke and $\mathrm{SO}_{2}$ were significantly associated with hospital admissions for all respiratory conditions at the $1 \%$ level. This was independent of temperature, pressure and humidity, all of which were entered into the regression model. The association was seen for hospital admissions without and with a two day lag. Daily level of smoke was associated with hospital admissions for asthma, lagged by two days at the $3 \%$ level, and the association between $\mathrm{SO}_{2}$ and asthma fell just below the 5\% significance level. Stepwise regression models revealed smoke and $\mathrm{SO}_{2}$ to be significant independent determinants of hospital admissions for both asthma and all respiratory conditions at or below the $5 \%$ level. Stepwise multiple regression including both pollutants revealed smoke, but not $\mathrm{SO}_{2}$ to be a significant independent determinant of wintertime hospital admissions for asthma and all respiratory conditions, lagged by two days, $x$-coefficient $2 \cdot 22$ ( $95 \%$ CI 1.23 to 3.22$), \mathrm{p}<0.00001$. There was no significant association between hospital admissions and daily air pollution levels during spring or autumn. During summer daily levels of smoke were significantly related to daily unlagged admissions for all respiratory diseases at the $1 \%$ level, and $\mathrm{SO}_{2}$ was significantly associated at the $2 \%$ level. The results of regression analysis using three day moving average levels of pollutants and daily hospital admissions were very similar to those using daily averages with hospital admissions lagged by two days (table 4 ).

A scatter plot of daily levels of smoke and $\mathrm{SO}_{2}$ and hospital admissions for all respiratory conditions lagged by two days during winter is shown in fig 4 . There is a broad scatter of points but no clear suggestion of a threshold for effect.

These results suggest that over the range of air pollution tested during winter a rise of $100 \mu \mathrm{g} / \mathrm{m}^{3}$ smoke might result in five $(95 \% \mathrm{CI}$ 0.6 to 9 ) more asthma admissions and 21.5 (95\% CI 10 to 33 ) more acute respiratory admissions a day in Birmingham. A $100 \mu \mathrm{g} / \mathrm{m}^{3}$ rise in $\mathrm{SO}_{2}$ might result in four (0 to 7) more asthma admissions and 15.5 (6 to 25) more respiratory admissions a day.

Weekly pollution levels and hospital admissions Results of multiple least squares regression using weekly mean pollution levels and weekly total hospital admissions are shown in table 5 . All regression models included meteorological variables which were significantly associated with hospital admissions during the season in question.

Significant associations $(p<0.01)$ were shown between all respiratory admissions and smoke and $\mathrm{SO}_{2}$ levels during winter, and 
Table 2 Mean (SE) and centile points for daily hospital admissions for respiratory disease and asthma in Birmingham, 1988-90

\begin{tabular}{|c|c|c|c|c|c|c|}
\hline & \multirow[t]{2}{*}{ Mean (SE) } & \multicolumn{5}{|c|}{ Centiles } \\
\hline & & $10 t h$ & $25 t h$ & $50 t h$ & $75 t h$ & $90 t h$ \\
\hline $\begin{array}{l}\text { All respirato } \\
\text { Spring } \\
\text { Summer } \\
\text { Autumn } \\
\text { Winter } \\
\text { All year }\end{array}$ & $\begin{array}{l}\text { s } \\
11.52(0.40) \\
12.32(0.38) \\
17.42(0.48) \\
17.48(0.64) \\
14.68(0.26)\end{array}$ & $\begin{array}{l}4 \\
6 \cdot 5 \\
10 \\
9 \\
7\end{array}$ & $\begin{array}{r}8 \\
8 \\
13 \\
12 \\
10\end{array}$ & $\begin{array}{l}11 \\
12 \\
17 \\
16 \\
14\end{array}$ & $\begin{array}{l}15 \\
16 \\
21 \\
21 \\
18\end{array}$ & $\begin{array}{l}19 \cdot 5 \\
20 \\
27 \\
30 \\
23\end{array}$ \\
\hline $\begin{array}{l}\text { Asthma } \\
\text { Spring } \\
\text { Summer } \\
\text { Autumn } \\
\text { Winter } \\
\text { All year }\end{array}$ & $\begin{array}{l}1.38(0.18) \\
4.88(0.20) \\
7.34(0.25) \\
5.27(0.23) \\
5.47(0.12)\end{array}$ & $\begin{array}{l}1 \\
2 \\
3 \\
2 \\
2\end{array}$ & $\begin{array}{l}3 \\
3 \\
5 \\
3 \\
3\end{array}$ & $\begin{array}{l}4 \\
4 \\
7 \\
5 \\
5\end{array}$ & $\begin{array}{r}6 \\
6 \\
10 \\
7 \\
7\end{array}$ & $\begin{array}{r}8 \\
9 \\
12 \\
9 \\
10\end{array}$ \\
\hline
\end{tabular}

between all respiratory admissions and $\mathrm{SO}_{2}$ levels only during autumn. All respiratory admissions were associated with weekly smoke levels in autumn but only at the 3\% level. Asthma admissions were not significantly associated with weekly levels of smoke or $\mathrm{SO}_{2}$ during any season. Stepwise multiple regres- sion models including both pollutants showed that, during winter, weekly $\mathrm{SO}_{2}$, but not smoke, levels were significantly associated with weekly hospital admissions for asthma $(p<0.005)$. All respiratory admissions were significantly associated with weekly smoke levels $(\mathrm{p}<0.001)$, but not $\mathrm{SO}_{2}$. During autumn $\mathrm{SO}_{2}$ was significantly associated with weekly admissions for all respiratory diseases $(\mathrm{p}<0.001)$. No significant associations between weekly total hospital admissions and weekly pollutant levels were found during spring or summer. During winter a rise of $25 \mu \mathrm{g} / \mathrm{m}^{3}$ in weekly mean smoke levels might result in 83 (95\% CI 44 to 122$)$ more respiratory admissions during the same week, and 43 (15 to 72 ) more asthma admissions.

\section{Association between meteorological conditions} and air pollution levels

The association between meteorological conditions (temperature, barometric pressure, and

Table 3 Multiple regression analysis: daily mean levels of sulphur dioxide and smoke $\left(\mu \mathrm{g} / \mathrm{m}^{3}\right)$ and daily total hospital admissions by season in Birmingham, 1988-90

Smoke v asthma Smoke vall respiratory $\quad \mathrm{SO}_{2} v$ asthma $\quad \mathrm{SO}_{2} v$ all respiratory diseases
diseases

\begin{tabular}{|c|c|c|c|c|}
\hline x-coefficient $(95 \% \mathrm{CI})$ & $0.006(-0.005$ to 0.06$)$ & $0.05(-0.07$ to 0.17$)$ & \\
\hline $\mathrm{p}$ value & NS & NS & NS & NS \\
\hline Variables significant in stepwise model & None & Pressure & None & Pressure \\
\hline \multicolumn{5}{|l|}{ Summer } \\
\hline $\mathrm{x}$-coefficient $(95 \% \mathrm{CI})$ & $0.057(-0.04$ to 0.16$)$ & $0.29(0.10$ to 0.48$)$ & $0.014(-0.10$ to 0.39$)$ & $0.059(0.011$ to 0.106$)$ \\
\hline $\begin{array}{l}p \text { value } \\
\text { Variables significant in stepwise model }\end{array}$ & $\begin{array}{l}\text { NS } \\
\text { None }\end{array}$ & $\begin{array}{l}<0.005 \\
\text { Smoke }\end{array}$ & & $<0.02$ \\
\hline \multicolumn{5}{|l|}{ Autumn } \\
\hline $\mathrm{x}$-coefficient $(95 \% \mathrm{CI})$ & $-0.018(-0.04$ to 0.01$)$ & $-0.001(-0.04$ to 0.4$)$ & $-0.019(-0.05$ to 0.13$)$ & $0.04(-0.18$ to 0.102$)$ \\
\hline p value & & NS & & NS \\
\hline Variables significant in stepwise model & None & Temperature & None & Temperature \\
\hline \multicolumn{5}{|l|}{ Winter } \\
\hline $\mathrm{x}$-coefficient $(95 \% \mathrm{CI})$ & $0.028(-0.014$ to 0.07$)$ & $0.20(0.094$ to 0.313$)$ & $0.027(-0.008$ to 0.061$)$ & $0.18(0.088$ to 0.268$)$ \\
\hline $\mathrm{p}$ value & & $<0.0005$ & & $<0.0002$ \\
\hline Variables significant in stepwise model & Smoke & Smoke, temperature & $\mathrm{SO}_{2}$, pressure & $\mathrm{SO}_{2}$, temperature, humidity \\
\hline \multirow{2}{*}{\multicolumn{5}{|c|}{$\begin{array}{l}\text { Hospital admissions lagged by two days } \\
\text { Spring }\end{array}$}} \\
\hline & & & & \\
\hline 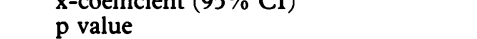 & NS & NS & NS & $\begin{array}{l}-0.03(-0.08 \text { to } 0.10) \\
\text { NS }\end{array}$ \\
\hline \multirow{2}{*}{\multicolumn{5}{|c|}{ Summer }} \\
\hline & & & & \\
\hline $\mathrm{x}$-coefficient $(95 \% \mathrm{CI})$ & $0.077(-0.022$ to 0.18$)$ & $0.15(-0.04$ to 0.35$)$ & $0.012(-0.013$ to 0.37$)$ & $0.029(-0.018$ to 0.08$)$ \\
\hline p value & $<0.2$ & $<0.2$ & & \\
\hline Variables significant in stepwise model & None & None & None & None \\
\hline \multicolumn{5}{|l|}{ Autumn } \\
\hline x-coefficient $(95 \% \mathrm{CI})$ & $-0.005(-0.03$ to 0.02$)$ & $0.007(-0.35$ to 0.49$)$ & $-0.011(-0.04$ to 0.22$)$ & $0.04(-0.02$ to 0.10$)$ \\
\hline $\begin{array}{l}\mathrm{p} \text { value } \\
\text { Variables significant }\end{array}$ & & $\mathbf{N}$ & & $<0 \cdot 2$ \\
\hline \multicolumn{5}{|l|}{ Winter } \\
\hline $\mathrm{x}$-coefficient $(95 \% \mathrm{CI})$ & $0.049(0.006$ to 0.093$)$ & $0.215(0.102$ to 0.327$)$ & $0.036(0.000$ to 0.073$)$ & $0.155(0.059$ to 0.251$)$ \\
\hline p value & $<0.05$ & 0.0002 & $<0 \cdot 1$ & $<0.002$ \\
\hline Variables significant in stepwise model & Smoke & Smoke, humidity & $\mathrm{SO}_{2}$ & $\mathrm{SO}_{2}$, temperature, humidity \\
\hline
\end{tabular}

Table 4 Multiple regression analysis: three day moving average levels of smoke and sulphur dioxide $v$ daily total hospital admissions in Birmingham, 1988-90

\begin{tabular}{|c|c|c|c|c|}
\hline Three day moving average pollution levels & Smoke $v$ asthma & $\begin{array}{l}\text { Smoke } v \text { all respiratory } \\
\text { diseases }\end{array}$ & $\mathrm{SO}_{2} v$ asthma & $\mathrm{SO}_{2} v$ all respiratory diseases \\
\hline $\begin{array}{l}\text { Spring } \\
\quad \mathrm{x} \text {-coefficient }(95 \% \mathrm{CI}) \\
\text { p value } \\
\text { Variables significant in stepwise model }\end{array}$ & $\begin{array}{l}-0.007(-0.09 \text { to } 0.07) \\
\text { NS } \\
\text { None }\end{array}$ & $\begin{array}{l}-0.02(-0.19 \text { to } 0 \cdot 16) \\
\text { NS } \\
\text { Pressure }\end{array}$ & $\begin{array}{l}-0.007(-0.03 \text { to } 0.16) \\
\text { NS } \\
\text { None }\end{array}$ & $\begin{array}{l}-0.03(-0.08 \text { to } 0.02) \\
\text { NS } \\
\text { Pressure }\end{array}$ \\
\hline $\begin{array}{l}\text { Summer } \\
\text { x-coefficient }(95 \% \mathrm{CI}) \\
\text { p value } \\
\text { Variables significant in stepwise model }\end{array}$ & $\begin{array}{l}0.021(-0.11 \text { to } 0 \cdot 15) \\
\text { NS } \\
\text { Humidity }\end{array}$ & $\begin{array}{l}0.25(-0.008 \text { to } 0.50) \\
0.05 \\
\text { None }\end{array}$ & $\begin{array}{l}0.016(-0.001 \text { to } 0.04) \\
\text { NS } \\
\text { Humidity }\end{array}$ & $\begin{array}{l}0.069(0.01 \text { to } 0.12) \\
<0.02 \\
\mathrm{SO}_{2}\end{array}$ \\
\hline $\begin{array}{l}\text { Autumn } \\
\text { x-coefficient }(95 \% \mathrm{CI}) \\
\text { p value } \\
\text { Variables significant in stepwise model }\end{array}$ & $\begin{array}{l}-0.03(-0.06 \text { to }-0.002) \\
<0.05 \\
\text { None }\end{array}$ & $\begin{array}{l}0.013(-0.4 \text { to } 0.7) \\
\text { NS } \\
\text { Temperature }\end{array}$ & $\begin{array}{l}-0.26(-0.7 \text { to } 0.13) \\
\text { NS } \\
\text { None }\end{array}$ & $\begin{array}{l}0.03(-0.04 \text { to } 0.11) \\
\text { NS } \\
\text { Temperature }\end{array}$ \\
\hline $\begin{array}{l}\text { Winter } \\
\text { x-coefficient }(95 \% \mathrm{CI}) \\
\text { p value } \\
\text { Variables significant in stepwise model }\end{array}$ & $\begin{array}{l}0.03(-0.02 \text { to } 0.078) \\
\text { NS } \\
\text { Pressure, temperature }\end{array}$ & $\begin{array}{l}0.29(0.17 \text { to } 0.42) \\
<0.0001 \\
\text { Smoke, temperature }\end{array}$ & $\begin{array}{l}0.039(0 \text { to } 0.78) \\
<0.05 \\
\mathrm{SO}_{2}, \text { pressure }\end{array}$ & $\begin{array}{l}0.23(0.14 \text { to } 0.33) \\
<0.0001 \\
\mathrm{SO}_{2}, \text { temperature }\end{array}$ \\
\hline
\end{tabular}




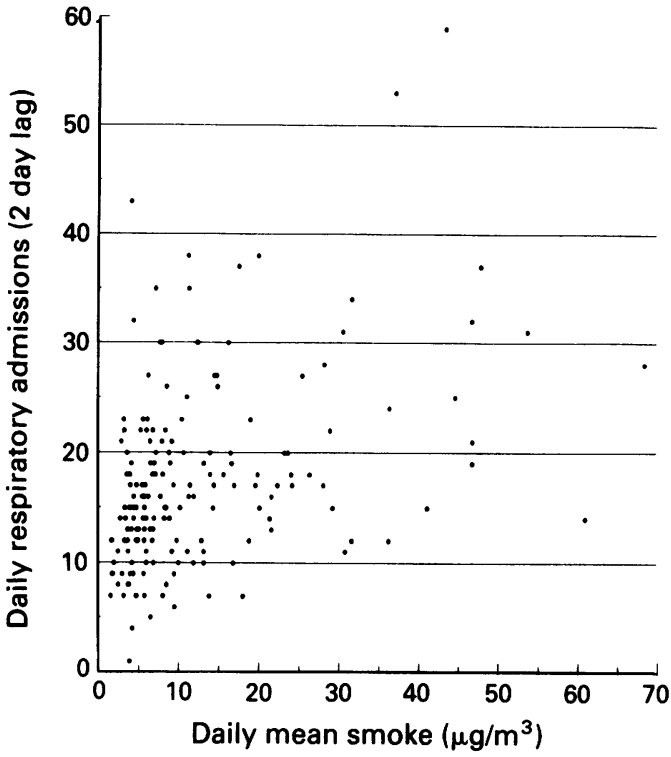

Figure 4 Scatter plot between daily mean smoke level and daily hospital admissions for respiratory disease, Birmingham, winter 1988-9 and 1989-90.

relative humidity) and levels of smoke and $\mathrm{SO}_{2}$ are shown by season in table 6 .

\section{Discussion}

This is the first recent study of the acute health effects of air pollutants in the UK on hospital admissions for respiratory diseases. We have shown that there is a significant association between hospital admissions for asthma and all respiratory conditions and air pollution levels during the winter at levels of air pollution which remained within EC guide levels, with the exception of one day. Associations at other times of year were present but weaker. These associations were independent of significant confounding meteorological variables (temperature, pressure, relative humidity). Smoke, and not $\mathrm{SO}_{2}$, was the important independent predictor of daily hospital admissions during winter, and of weekly admissions for all respiratory conditions. This confirms the potential importance of health effects of particulates from the studies of Pope et al in Utah where PM10 was found to be a significant predictor of a wide range of respiratory morbidity at very low concurrent levels of $\mathrm{SO}_{2}{ }^{11121415} \mathrm{SO}_{2}$ was a significant predictor of weekly asthma admissions.

These associations were weak, but statistically significant, and consistent in strength with those found in other studies..$^{8-10}$ However, the North American studies ${ }^{89}$ found significant associations between hospital admissions and attendances and air pollution levels during summer, whereas this study has found significant associations mainly during winter. This may reflect climatic differences resulting in differences in seasonality of air pollution peaks. In the study of COPD admissions in Barcelona, seasonal breakdown revealed strongest associations between black smoke and emergency room admissions for COPD in winter, ${ }^{10}$ while associations between $\mathrm{SO}_{2}$ levels and admissions were strongest in summer. Both pollutants were significantly associated with pollutants in all seasons except autumn. However, mean levels of both $\mathrm{SO}_{2}$ and, particularly, black smoke were higher in Barcelona than in Birmingham $\left(56.5 \mu \mathrm{g} / \mathrm{m}^{3}\right.$ and $72.9 \mu \mathrm{g} / \mathrm{m}^{3}$ respectively). The results of this

Table 5 Multiple regression analysis: weekly mean smoke and sulphur dioxide levels v weekly total hospital admissions in Birmingham, 1988-90

\begin{tabular}{|c|c|c|c|c|}
\hline Weekly average pollution levels & Smoke $v$ asthma & $\begin{array}{l}\text { Smoke } v \text { all respiratory } \\
\text { diseases }\end{array}$ & $\mathrm{SO}_{2} v$ asthma & $\mathrm{SO}_{2} v$ all respiratory diseases \\
\hline $\begin{array}{l}\text { Spring } \\
\text { x-coefficient }(95 \% \mathrm{CI}) \\
\text { p value } \\
\text { Variables significant in stepwise model }\end{array}$ & $\begin{array}{l}0 \cdot 103(-1.24 \text { to } 1 \cdot 44) \\
\text { NS } \\
\text { None }\end{array}$ & $\begin{array}{l}-0 \cdot 13(-3 \cdot 7 \text { to } 3 \cdot 44) \\
\text { NS } \\
\text { None }\end{array}$ & $\begin{array}{l}-0.096(-0.39 \text { to } 0.19) \\
\text { NS } \\
\text { None }\end{array}$ & $\begin{array}{l}-0.39(-1.15 \text { to } 0.37) \\
\text { NS } \\
\text { None }\end{array}$ \\
\hline $\begin{array}{l}\text { Summer } \\
\text { x-coefficient }(95 \% \mathrm{CI}) \\
\text { p value } \\
\text { Variables significant in stepwise model }\end{array}$ & $\begin{array}{l}1.14(-0.88 \text { to } 3.17) \\
\text { NS } \\
\text { None }\end{array}$ & $\begin{array}{l}3.42(0.08 \text { to } 6.77) \\
<0.05 \\
\text { None }\end{array}$ & $\begin{array}{l}0.167(-0.12 \text { to } 0.54) \\
\text { NS } \\
\text { None }\end{array}$ & $\begin{array}{l}0.59(-0.023 \text { to } 1.22) \\
<0.1 \\
\text { None }\end{array}$ \\
\hline $\begin{array}{l}\text { Autumn } \\
\text { x-coefficient }(95 \% \mathrm{CI}) \\
\text { p value } \\
\text { Variables significant in stepwise model }\end{array}$ & $\begin{array}{l}0.176(-0.41 \text { to } 0.76) \\
\text { NS } \\
\text { None }\end{array}$ & $\begin{array}{l}1.07(0.11 \text { to } 2.03) \\
<0.05 \\
\text { Smoke }\end{array}$ & $\begin{array}{l}0.46(-0.05 \text { to } 0.96) \\
<0 \cdot 1 \\
\text { None }\end{array}$ & $\begin{array}{l}1.38(0.596 \text { to } 2.16) \\
<0.002 \\
\mathrm{SO}_{2}\end{array}$ \\
\hline $\begin{array}{l}\text { Winter } \\
\text { x-coefficient }(95 \% \mathrm{CI}) \\
\text { p value } \\
\text { Variables significant in stepwise model }\end{array}$ & $\begin{array}{l}0.5(-0.25 \text { to } 1.24) \\
\text { NS } \\
\text { Smoke }\end{array}$ & $\begin{array}{l}3.30(1.75 \text { to } 4.87) \\
<0.0005 \\
\text { Smoke, humidity }\end{array}$ & $\begin{array}{l}0.443(0 \text { to } 0.89) \\
0.05 \\
\mathrm{SO}_{2}\end{array}$ & $\begin{array}{l}1.72(0.58 \text { to } 2.87) \\
0.005 \\
\mathrm{SO}_{2}, \text { humidity }\end{array}$ \\
\hline
\end{tabular}

Note: Stepwise regression models including meteorological variables of temperature, pressure and humidity, and both pollutants gave the following significant results:

Autumn: All respiratory $\mathrm{SO}_{2}$ significant ( $\mathrm{x}$-coefficient $1.59,0.91$ to $2 \cdot 27, \mathrm{p}<0.001$ )

Winter: All respiratory smoke significant (x-coefficient $3.37,2 \cdot 10$ to $4.64, \mathrm{p}<0.0001$ ). Asthma, $\mathrm{SO}_{2}$ significant $(\mathrm{x}$-coefficient $0.63,0.25$ to $1.01, \mathrm{p}<0.005)$.

Table 6 Association between levels of smoke and sulphur dioxide and meteorological variables (temperature, pressure, humidity) ( $x$-coefficients and $p$ values given)

\begin{tabular}{lcccc}
\hline & Spring & Summer & Autumn & Winter \\
\hline Smoke & & & & \\
Temperature & $0.18(\mathrm{NS})$ & $0.27(\mathrm{p}<0.001)$ & $-2.28(\mathrm{p}<0.0001)$ & $-1.75(\mathrm{p}<0.0001)$ \\
Pressure & $0.87(\mathrm{p}<0.1)$ & $0.21(\mathrm{p}<0.0001)$ & $0.69(\mathrm{p}<0.0001)$ & $0.19(\mathrm{p}<0.001)$ \\
Humidity & $-0.02(\mathrm{NS})$ & $-0.05(\mathrm{p}<0.02)$ & $0.27(\mathrm{p}<0.05)$ & $0.229(\mathrm{p}<0.005)$ \\
Sulphur dioxide & & & & \\
Temperature & $0.70(\mathrm{p}<0.05)$ & $0.31(\mathrm{p}<0.0001)$ & $-1.69(\mathrm{p}<0.0001)$ & $-1.53(\mathrm{p}=0.0001)$ \\
Pressure & $0.24(\mathrm{p}<0.1)$ & $0.71(\mathrm{p}<0.0001)$ & $0.69(\mathrm{p}<0.0001)$ & $0.195(\mathrm{p}=0.0007)$ \\
Humidity & -0.14 (NS) & $-0.19(\mathrm{p}<0.05)$ & $0.06(\mathrm{NS})$ & $0.193(\mathrm{p}<0.05)$ \\
\hline
\end{tabular}


study are more consistent with those from Barcelona than the North American studies, and suggest that, in a European winter, particulate pollution below the EC guide level may be associated with significant health effects.

The associations between air pollution levels and hospital admissions observed in winter in this study may indicate that smoke and $\mathrm{SO}_{2}$ are contributory causes of acute respiratory episodes, or that other confounding factors are operating. This analysis controlled for the effects of temperature, pressure, and humidity by including them in the regression model. However, it cannot control for other covariates which may have a confounding effect. This includes behavioural covariates. Cold weather is associated with higher levels of pollutants, but may also make people use more heating, and stay indoors more. The use of heating may result in higher exposure to indoor air pollutants from fuel including oxides of nitrogen which can influence the prevalence of respiratory symptoms. ${ }^{41}$ Staying indoors may also assist in the transmission of viral upper respiratory tract infections, and increase exposure of atopic subjects to indoor allergens such as house dust mite. All these factors, not directly associated with outdoor air pollution levels, may thus produce a confounding effect and could not be measured in this study. Air pollution may be acting as an indicator for other triggers as well as a direct trigger of respiratory episodes in itself.

The relative absence of associations between daily hospital admissions and air pollution during other seasons is interesting. Firstly, in this study we only measured $\mathrm{SO}_{2}$ and smoke, but particularly during the summer these may covary with other pollutants present on hot sunny days with low winds and high barometric pressure, in particular ozone, oxides of nitrogen, and acid aerosols. They may also covary with grass pollen and other triggers for asthmatic attacks. The only significant association seen during summer was between all respiratory conditions and both smoke and $\mathrm{SO}_{2}$ levels, but without any lagged effect. This suggests that the association may be due to covariation between these pollutants and other environmental triggers for respiratory disease. The British black smoke method of measuring particulates only measures coloured particulate matter, of which a large proportion comes from diesel vehicle exhausts. ${ }^{40}$ However, the proportion of total particulates accounted for by the black smoke fraction may vary between seasons and with meteorological conditions. This means that black smoke may be a relatively poor index of total particulate exposure, and makes interpretation of negative results difficult. Finally, associations were noted during winter which is the season during which highest levels of smoke are seen. This may represent a threshold effect.

There are problems associated with the use of hospital admissions as an index of respiratory morbidity. Hospital admissions represent a complex social and behavioural process and may be influenced by factors not directly related to disease severity. If the behavioural influences on hospital admission covary with pollution levels or weather conditions, this might influence the associations seen in this study. Factors such as pet ownership, smoking, heating and cooking methods, family history, and occupation might be expected to affect the prevalence of respiratory disease, but do not show rapid changes over time and are unlikely to act as confounding factors in this study.

This study was restricted by data availability to investigating the effects of $\mathrm{SO}_{2}$ and smoke, both of which are now at low levels compared with 30 years ago and have not shown any tendency to rise over the previous decade. ${ }^{2}$ It would be difficult to propose that these pollutants are the cause of rising levels of hospital admissions for asthma in the West Midlands Region. Recent concern about the health effects of air pollution has centred around pollutants associated with motor vehicles, including oxides of nitrogen, hydrocarbons, and diesel exhaust particulates. ${ }^{42} \mathrm{Al}-$ though black smoke is quite a good measure of diesel exhaust particulates in an urban area, no measurements of oxides of nitrogen, hydrocarbons, or ozone were made at the time of this study. Evaluation of their health effects and covariance with smoke and $\mathrm{SO}_{2}$ must await analysis of recently installed monitoring equipment as part of the extended urban air pollution monitoring network established by the Department of the Environment in Birmingham and other cities in the UK.

Although weather conditions are important determinants of air pollution levels in Birmingham, clean air legislation has proved that action to control emissions has been successful. ${ }^{2}$ However, the cost of further reductions in emissions from motor vehicles and other important industrial sources must be balanced against the potential health improvements achieved. This study has shown that routinely collected data can be used, with certain limitations, to assess the potential health effects of air pollution and potential benefits of reducing levels. However, in view of potential confounding factors, further more specific population based and panel based studies are needed to establish the weight of effect of environmental factors, including air pollution, on respiratory health.

1 Ministry of Health. Mortality and morbidity during the London fog of December 1952. London: HMSO, 1954.

2 Quality of Urban Air Review Group. Urban air quality in the United Kingdom. London: Department of the Environment, 1993.

3 Schwartz J. Particulate air pollution and daily mortality in Detroit. Environ Res 1991;56:204-13.

4 Schwartz J, Dockery DW. Increased mortality in Philadelphia associated with daily air pollution concentrations. Am Rev Respir Dis 1992;145:600-4.

5 Schwartz J, Dockery DW. Particulate air pollution and daily mortality in Steubenville, Ohio. Am $\mathcal{f}$ Epidemiol 1992;135:12-9.

6 Pope CA, Schwartz J, Ransom MR. Daily mortality and PM10 pollution in Utah valley. Arch Environ Health 1992;47:211-7.

7 Levy D, Gent M, Newhouse MT. Relationship between acute respiratory illness and air pollution levels in an industrial city. Am Rev Respir Dis 1977;116:167-73.

8 Bates DV, Sizto R. Air pollution and hospital admissions in Southern Ontario: the acid summer haze effect. Environ Res 1987;43:317-31

9 Bates DV, Baker-Anderson M, Sizto R. Asthma attack periodicity: a study of hospital emergency visits in Vancouver. Environ Res 1990;51:51-70. 
10 Sunyer J, Anto JM, Murillo C, Saez M. Effects of urban air pollution on emergency room admissions for chronic pollution on emergency room admissions for chronic
obstructive pulmonary disease. $A m$ Epidemiol obstructive pulmon

11 Pope CA. Respiratory disease associated with community air pollution and a steel mill in Utah Valley. Am $\mathcal{F}$ Public Health 1989;79:623-8.

12 Pope CA. Respiratory hospital admissions associated with PM10 pollution in Utah, Salt Lake and Cache Valleys. Arch Environ Health 1991;46:90-7.

13 Schwartz J, Slater D, Larson TV, Pierson WE, Koenig WQ. Particulate air pollution and hospital emergency visits for asthma in Seattle. Am Rev Respir Dis visits for asthma in
1992;145(4 part 2):A88.

14 Ransom MR, Pope CA. Elementary school absences and PM10 pollution in Utah Valley. Environ Res 1992;58:204 19.

15 Pope CA, Dockery DW. Acute health effects of PM10 pollution on symptomatic and asymptomatic children Am Rev Respir Dis 1992;145:1123-8.

16 Waller RE. Air pollution and community health. $f R$ Col Physicians Lond 1971;5:362-8.

17 Dassen W, Brunekreef B, Hoek G, Hofschreuder P, Staasen $\mathrm{B}$, de-Groote $\mathrm{H}$, et al. Decline in children's lung function during an air pollution episode. $\mathcal{f} \mathrm{Am}$ Poll Control Assoc during an air po

18 Brunekreef B, Lumens $M$, Hoek G, Hofschreuder $P$ Fischer P, Biersteker K. Pulmonary function changes associated with an air pollution episode in January $1987 . \mathcal{J}$ Am Poll Control Assoc 1989;39:1444-7.

19 Hoek G, Brunekreef B, Roemer W. Acute effects of moderately elevated wintertime air pollution on respiratory health of children $A m$ Rev Respir Dis 1991:142(4 part 2):A88.

20 Neas LM, Dockery DW, Spengler JD, Speitzer FE, Tollend DJ. The association of ambient air pollution with twice daily peak respiratory flow measurements in children. Am Rev Respir Dis 1992;145(4 part 2):A429.

21 Schwartz J, Spix C, Wichmann HE, Malin E. Air pollution and acute respiratory illness in five German communities. Environ Res 1991;56:1-14.

22 Ostro BD, Lipsett MJ, Wiener MB, Selner JC. Asthmatic responses to airborne acid aerosols. Am $\mathcal{f}$ Public Health 1991;81:694-702.

23 Whittemore AS, Korn EL. Asthma and air pollution in the Los Angeles area. Am f Public Health 1980;70:687-97.

24 Spektor DM, Thurston GD, Mao J, He D, Hayes C, Lippman M. Effects of single and multiday ozone exposures on respiratory function in active normal children. sures on respiratory function

25 Lioy PJ, Vollmujth TA, Lipmann M. Persistence of peak flow decrement in children following ozone exposure exceeding the National Ambient Air Quality Standard. $\mathcal{F}$ Am Poll Control Assoc 1985;35:1068-71.

26 Lawther PJ, McFarlane AJ, Waller RE, Brooks AGF. Pulmonary function and sulfur dioxide - some preliminary findings. Environ Res 1975;10:355-67.

27 Sheppard D, Wong WS, Uehara CF, Nadel JA, Boushey
HA. Lower threshold and greater bronchomotor responsiveness of asthmatic subjects to sulfur dioxide. Am Rev Respir Dis 1980;122:873-8.

28 Linn WS, Venet TG, Shamoo DA, Valencia LM, Anzar UT, Speir CE, et al. Respiratory effects of sulfur dioxide in heavily-exercising asthmatics: a dose-response study. Am Rev Respir Dis 1983;127:278-83.

29 Linn WS, Avol EL, Penc R-C, Shamoo SA, Hackney JD. Replicated dose-response study of sulfur dioxide effects in normal, atopic and asthmatic volunteers. Am Rev Respir Dis 1987;136:1127-34.

30 Balmes JR, Fine JM, Sheppard D. Symptomatic bronchoconstriction after short-term inhalation of sulfur dioxide. Am Rev Respir Dis 1987;136:1117-21.

31 Hazucha MJ. Relationship between ozone exposure and pulmonary function changes. $\mathcal{f}$ Appl Physiol 1987;62:1671-80.

32 Linn WS, Avol EL, Shamoo DA, Speir CE, Valencia LM, Venet TG, et al. Dose response study of healthy heavilyexercising men exposed to ozone at concentrations near the ambient air quality standard. Toxicol Ind Health 1986;2:99-112.

33 Orehek J, Massoni JP, Gattard C, Charpin J. Effect of short term low level nitrogen dioxide exposure on bronchial sensitivity of asthmatic patients. $\mathcal{f}$ Clin Invest 1986;56:301-7.

34 Molfino NA, Wright SC, Katz I, Tarlo S, Silverman F, McClean PA, et al. Effect of low concentrations of ozone on inhaled allergen responses in asthmatic subjects. Lancet 1991;338:199-203.

35 Ware JH, Ferris BG Jr, Dockery DW, Spengler JD, Stram DO, Speizer FE. Effects of sulfur oxides and suspended particulates on respiratory health of preadolescent children. Am Rev Respir Dis 1986;133:834-42.

36 Dockery DW, Speizer FE, Stram DO, Ware JH, Spengler JD, Ferris BG Jr. Effects of inhalable particulates on
respiratory health of children. Am Rev Respir Dis respiratory health

37 West Midlands Regional Health Authority. Partners in Health: Annual Report of the Regional Director of Public Health. West Midlands RHA, 1992.

38 Harrison RM. Important air pollutants and their chemical analysis. In Harrison RM, ed. Pollution: causes, effects and control. Cambridge: Royal Society of Chemistry, 1990:127-55.

39 Clarke AG, Willison MJ, Ziki EM. A comparison of urban and rural aerosol composition using a dichotomous sampler. Atmos Environ 1984;23:1767-75.

40 Ball DJ, Caswell R. Smoke from diesel engined road vehicles - an investigation into the basis of British and European emission standards. Atmos Environ 1983;17:169-81.

41 Neas LM, Dockery DW, Ware JH, Spengler JD, Speizer FE, Ferris BG Jr. Association of indoor nitrogen dioxide with respiratory symptoms and pulmonary function in children. Am $\mathcal{f}$ Epidemiol 1991;134:204-19.

42 Godlee F. Air pollution: II. Road traffic and modern industry. $B M \mathcal{F} 1991 ; 303: 1539-43$. 